\title{
The susceptibility of cochlear outer hair cells to cyclodextrin is not related to their electromotile activity
}

\author{
Yingjie Zhou ${ }^{1 \dagger}$, Satoe Takahashi ${ }^{2 \dagger}$, Kazuaki Homma ${ }^{2,3}$, Chongwen Duan², Jason Zheng ${ }^{2}$, \\ Mary Ann Cheatham ${ }^{1,3}$ and Jing Zheng ${ }^{1,2,3^{*}}$ (I)
}

\begin{abstract}
Niemann-Pick Type C1 (NPC1) disease is a fatal neurovisceral disorder caused by dysfunction of NPC1 protein, which plays a role in intracellular cholesterol trafficking. The cholesterol-chelating agent, 2-hydroxypropyl- $\beta$ cyclodextrin (HP $\beta C D)$, is currently undergoing clinical trials for treatment of this disease. Though promising in alleviating neurological symptoms, HP $\beta C D$ causes irreversible hearing loss in NPC1 patients and outer hair cell $(\mathrm{OHC})$ death in animal models. We recently found that HP $\beta C D$-induced $\mathrm{OHC}$ death can be significantly alleviated in a mouse model lacking prestin, an OHC-specific motor protein required for the high sensitivity and sharp frequency selectivity of mammalian hearing. Since cholesterol status is known to influence prestin's electromotility, we examined how prestin contributes to HPBCD-induced OHC death in the disease context using the NPC1 knockout (KO) mouse model (NPC1-KO). We found normal expression and localization of prestin in NPC1-KO OHCs. Wholecell patch-clamp recordings revealed a significant depolarization of the voltage-operating point of prestin in NPC1$\mathrm{KO}$ mice, suggesting reduced levels of cholesterol in the lateral membrane of OHCs that lack NPC1. OHC loss and elevated thresholds were found for high frequency regions in NPC1-KO mice, whose OHCs retained their sensitivity to HP $\beta C D$. To investigate whether prestin's electromotile function contributes to HPBCD-induced OHC death, the prestin inhibitor salicylate was Co-administered with HPBCD to WT and NPC1-KO mice. Neither oral nor intraperitoneal administration of salicylate mitigated HPBCD-induced OHC loss. To further determine the contribution of prestin's electromotile function, a mouse model expressing a virtually nonelectromotile prestin protein (499-prestin) was subjected to HPßCD treatment. 499-prestin knockin mice showed no resistance to HP $\beta C D$-induced OHC loss. As 499-prestin maintains its ability to bind cholesterol, our data imply that HPßCDinduced $\mathrm{OHC}$ death is ascribed to the structural role of prestin in maintaining the $\mathrm{OHC}^{\prime}$ s lateral membrane, rather than its motor function.
\end{abstract}

Keywords: Prestin, Niemann-pick type C1, HPßCD, Cholesterol, Salicylate, Electromotility, Outer hair cells

\section{Introduction}

Cyclodextrins (CDs) comprise a family of amphipathic cyclic oligosaccharides with a hydrophobic core and a hydrophilic outer surface. Because CDs can complex with hydrophobic molecules to enhance their solubility, they have been widely used in the pharmaceutical

\footnotetext{
* Correspondence: jzh215@northwestern.edu

†Yingjie Zhou and Satoe Takahashi contributed equally to this work.

${ }^{1}$ Department of Communication Sciences and Disorders, Northwestern

University, Evanston, IL 60208, USA

${ }^{2}$ Department of Otolaryngology - Head and Neck Surgery, Feinberg School

of Medicine, Northwestern University, Chicago, IL 60611, USA

Full list of author information is available at the end of the article
}

industry to facilitate drug delivery [50]. More recently, CDs themselves have become attractive therapeutic candidates that can extract lipids and cholesterol from cell membranes to treat cardiovascular and neurodegenerative diseases [11]. One such example is 2-hydroxypropyl$\beta$-cyclodextrin (HP $\beta C D$ ), which is currently undergoing a clinical trial for the treatment of a rare genetic disease called Niemann-Pick Type C1 (NPC1) [34, 35]. In NPC1 disease, lack or dysfunction of NPC1 protein that resides in endosomal and lysosomal membranes [27] disturbs intracellular cholesterol trafficking, resulting in progressive neural degeneration and early death in affected

(c) The Author(s). 2018 Open Access This article is distributed under the terms of the Creative Commons Attribution 4.0 International License (http://creativecommons.org/licenses/by/4.0/), which permits unrestricted use, distribution, and reproduction in any medium, provided you give appropriate credit to the original author(s) and the source, provide a link to the Creative Commons license, and indicate if changes were made. The Creative Commons Public Domain Dedication waiver (http://creativecommons.org/publicdomain/zero/1.0/) applies to the data made available in this article, unless otherwise stated. 
individuals. $\mathrm{HP} \beta C D$ administration drastically improves the neurological symptoms of both NPC1 animal models and human patients; however, hearing loss is reported to be a common outcome associated with $\mathrm{HP} \beta C D$ treatment $[12,13,17,22,55]$.

Since hearing loss is an unavoidable adverse effect of $\mathrm{HP} \beta C D$ therapy in NPC1 patients, understanding the mechanisms underlying its ototoxicity is of high interest. In animal models, HP $\beta C D$-induced hearing loss is associated with loss of outer hair cells (OHCs) [13]. OHCs function as cochlear amplifiers by undergoing somatic length changes, called electromotility [5], which are required for sensitivity and frequency selectivity in mammalian hearing [15]. OHC electromotility is mediated by a distinctive motor protein, prestin [59], which belongs to a family of solute carrier protein 26 (SLC26) anion transporters. Prestin (SLC26A5) is unusual among the SLC26 family as it exhibits robust voltage-dependent conformational changes that confer electromotility. Recently, we discovered that $\mathrm{HP} \beta \mathrm{CD}$-induced $\mathrm{OHC}$ death is exacerbated by the presence of prestin, as OHCs lacking prestin were less vulnerable to $\mathrm{HP} \beta C D$ [45]. We further demonstrated that prestin can directly interact with cholesterol, suggesting that the extraction of cholesterol by $\mathrm{HP} \beta C D$ may disrupt the prestin-rich membrane, resulting in rapid $\mathrm{OHC}$ death [45]. Although prestin contributes to the OHC's sensitivity to cholesterol depletion, it is not clear how prestin influences HP $\beta C D$-evoked $\mathrm{OHC}$ death or whether prestin's motile function contributes to its vulnerability to $\mathrm{HP} \beta C D$ treatment.

The OHC's lateral membrane is packed with $\sim 11 \mathrm{~nm}$ particles composed of prestin tetramers $[25,54,58]$. In fact, removing prestin results in a $40 \%$ decrease in $\mathrm{OHC}$ length [8], indicating that cholesterol concentration and the lipid environment are probably wild-type (WT)-like, as cell surface area decreases proportionally in OHCs lacking prestin. Although cholesterol molecules bound to WT prestin could be the reason that $\mathrm{OHCs}$ are more sensitive to $\mathrm{HP} \beta C D$ treatment, we cannot rule out the possibility that prestin's motile function may also contribute to susceptibility, as cholesterol is known to influence both motility and oligomerization [21, 37]. Prestin's motile function is based on its ability to change its conformation when membrane voltage is changed. As $\beta$-cyclodextrin is capable of changing protein conformation [18], whether prestin's motile function contributes to its vulnerability to $\mathrm{HP} \beta C D$ treatment requires investigation.

In this study, we sought to understand the molecular mechanisms underlying $\mathrm{HP} \beta \mathrm{CD}$-induced $\mathrm{OHC}$ death in the disease context. NPC1 patients present with variable degrees of hearing impairment even before receiving their first HP $\beta C D$ treatment [24]. The NPC1-knockout (KO) mouse model (also known as $N P C^{\text {nih }}$ ) that lacks NPC1 expression exhibits hearing impairment well before the onset of overt neurological symptoms [23]. These observations suggest that NPC1 plays important roles directly or indirectly in hearing, as decreased $\mathrm{OHC}$ performance was detected by measuring distortion product otoacoustic emissions (DPOAE). Since cholesterol has an enormous influence on prestin's function and structure [21, 37], we first tested whether the expression, localization, and/or function of prestin is influenced in the NPC1 disease context using the NPC1-KO mouse model. Our data show that lack of NPC1 protein does not affect the normal distribution pattern of prestin protein. Using an electrophysiological method, we assessed function of prestin by measuring nonlinear capacitance (NLC), a proxy for electromotility. OHCs isolated from NPC1-KOs exhibited robust NLC indicating that prestin-based somatic elec tromotility is present, although its sensitivity and voltage dependence are altered relative to WT prestin. Consistent with normal prestin expression, OHCs from NPC1-KOs are as sensitive to $\mathrm{HP} \beta C D$ as WT. In order to determine whether the motile function of prestin contributes to the $\mathrm{HP} \beta C D$-induced ototoxicity, we utilized the prestin inhibitor salicylate, a commonly used painkiller and anti-inflammatory drug known as aspirin. Salicylate competes with prestin's substrates such as chloride and bicarbonate, thereby reversibly inhibiting function [33]. Co-administration of salicylate and $\mathrm{HP} \beta C D$ did not mitigate $\mathrm{HP} \beta C D$-induced $\mathrm{OHC}$ death, indicating that inhibition of prestin's electromotility did not affect the sensitivity of OHCs to $\mathrm{HP} \beta C D$. We further tested the contribution of prestin's motile function using a prestin knockin (KI) mouse model that expresses virtually nonfunctional 499-prestin protein (499-prestin-KI) [16]. 499-prestin KI mice were as sensitive to $\mathrm{HP} \beta \mathrm{CD}$-induced $\mathrm{OHC}$ loss as WT, suggesting that prestin's motor action is not the key factor underlying the $\mathrm{OHC}$ 's sensitivity to HP $\beta C D$. Since 499 -prestin targets the lateral membrane and interacts with cholesterol as in WT prestin, OHC loss appears to be determined by the presence of cholesterol-interacting prestin proteins that confer normal $\mathrm{OHC}$ stiffness and length, rather than to its electromotile function.

\section{Material and methods Animals}

All experimental procedures were conducted in accordance with the Guide for the Care and Use of Laboratory Animals, and were approved by Northwestern University's Animal Care and Use Committee and the National Institutes of Health. NPC1-KO mice (BALB/cNctr-Npc1 ${ }^{m 1 N}$, also known as $N P C^{\text {nih }}$ ) were obtained from The Jackson Laboratory (Stock No: 003092). Wild-type (WT) and NPC1-KO mice were obtained by heterozygous breeding. Genotyping was outsourced to Transnetyx (Cordova, TN). Mice younger than 2.5 months (age) were used to avoid complications from neurological dysfunction due to loss 
of NPC1. 499-prestin-KI mice that carry the V499G/ $\mathrm{Y} 501 \mathrm{H}$ mutation in the prestin gene were maintained on the original 129S6/C57Bl6J background [16]. 499-KI mice younger than 1 month of age were used to minimize $\mathrm{OHC}$ loss [8]. In all experiments, both males and females were tested.

\section{$H P \beta C D$ and $H P \beta C D /$ salicylate treatments}

WT and 499-prestin-KI mice were injected with saline or HPßCD (Sigma, H107) dissolved in saline $(0.9 \% \mathrm{NaCl})$ subcutaneously as described previously [45]. For low-dose $(4000 \mathrm{mg} / \mathrm{kg})$ treatment, mice were repeatedly injected four times once per week for four weeks. For high-dose $(8000 \mathrm{mg} / \mathrm{kg})$ treatment, mice were injected once. For oral administration of salicylate, adult mice (P32-43) were supplied with drinking water containing $3 \mathrm{mg} / \mathrm{ml}$ sodium salicylate for 7 days prior to high-dose HP $\beta C D$ subcutaneous injection. Salicylate water bottles were changed twice per week. Animals were returned to regular water $24 \mathrm{~h}$ after $\mathrm{HP} \beta C D$ injection. For intraperitoneal administration of salicylate, mice (P32-45) were first injected with sodium salicylate $(245 \mathrm{mg} / \mathrm{kg})$ a day before $\mathrm{HP} \beta C D$ treatment. Approximately, $16 \mathrm{~h}$ later, a second salicylate injection was administered as described before [57]. Within $1 \mathrm{~h}$, mice were screened using DPOAEs and auditory brainstem responses (ABR), and then injected with $8000 \mathrm{mg} / \mathrm{kg}$ HP $\beta C D$ subcutaneously, i.e., $\sim 1 \mathrm{~h}$ after the second salicylate injection. Since salicylate is known to be eliminated from the blood after $8 \mathrm{~h}$ in mice [44], these animals were also supplied with water containing $3 \mathrm{mg} / \mathrm{ml}$ sodium salicylate, but returned to regular water $24 \mathrm{~h}$ after HP $\beta C D$ injection. Control mice were supplied with regular water and injected with saline. Auditory function was measured before and after $\mathrm{HP} \beta C D$ injection.

\section{Cochlear in vivo physiology}

WT and NPC1-KO mice were anaesthetized with intraperitoneal injections of ketamine $\left(100 \mathrm{mg} \mathrm{kg}^{-1}\right)$ and xylazine $\left(10 \mathrm{mg} \mathrm{kg}^{-1}\right)$. Additional doses were given throughout the experiment to maintain a surgical level of anesthesia. During data collection, body temperature was maintained using a heating blanket. DPOAE were measured by presenting the two stimulating primaries ( $\mathrm{f} 2 / \mathrm{f} 1=1.2)$ at $70 \mathrm{~dB}$ SPL or when the level of $\mathrm{f} 1$ was $50 \mathrm{~dB}$ SPL and the level of $\mathrm{f} 2$ as $35 \mathrm{~dB}$ SPL. Growth or input-output functions were also acquired for $\mathrm{f} 2=$ $12 \mathrm{kHz}$ and for $\mathrm{f} 2=27 \mathrm{kHz}$. For these measurements, the level of $\mathrm{f} 1$ was always $10 \mathrm{~dB}$ higher than that for $\mathrm{f} 2$. In order to obtain a measure of sensitivity, DPOAE thresholds were determined as the level of $\mathrm{f} 1$ that generated $2 \mathrm{f} 1-\mathrm{f} 2$ of $0 \mathrm{~dB}$. ABRs to tone-burst stimuli were then collected to document the output of the cochlea, as well as the brainstem. For these recordings, subcutaneous electrodes were inserted at the vertex and the mastoid with each response measured relative to the indifferent electrode inserted into the opposite shoulder/ neck region. Calibration was performed quasi-free field as reported previously [36]. Thresholds were determined by noting the signal level where the $A B R$ waveform disappeared into the noise. Because the number of averages increased as signal level decreased ( $5 \mathrm{~dB}$ step size), the noise level was $\sim 0.2$ microvolts. Further details on how these recordings are made appear in a previous publication [9]. All DPOAE and ABR measurements were completed on the same day.

\section{Nonlinear capacitance (NLC) measurements}

OHCs were isolated from P29-78 mice for NLC recordings. Whole-cell recordings were performed at room temperature using the Axopatch 200A amplifier (Molecular Devices, CA). Recording pipettes were pulled from borosilicate glass to achieve initial bath resistances averaging 3 4 $\mathrm{M} \Omega$. Intracellular pressure was kept at $0 \mathrm{mmHg}$ during recording. Recording pipettes were filled with an intracellular solution containing $(\mathrm{mM})$ : $140 \mathrm{CsCl}, 2 \mathrm{MgCl} 2,10 \mathrm{EGTA}$, and 10 HEPES (pH 7.3). $\mathrm{OHCs}$ were isolated from WT and NPC-KO mice and bathed in an extracellular solution containing (mM): 120 $\mathrm{NaCl}, 20$ TEA-Cl, $2 \mathrm{CoCl} 2,2 \mathrm{MgCl} 2,10$ HEPES (pH 7.3). Osmolarity was adjusted to $310 \mathrm{mmol} / \mathrm{kg}$ with glucose. NLC was measured using a sinusoidal voltage stimulus $(2.5-\mathrm{Hz}, 120$ or $150 \mathrm{mV}$ amplitude) upon which two higher frequency stimuli were superimposed (391 and $781 \mathrm{~Hz}, 10 \mathrm{mV}$ amplitude). Data were collected by jClamp (SciSoft Company, New Haven, CT), and NLC determined, as described previously [19, 41]. Voltagedependent cell membrane electrical capacitance data were analyzed using the following two-state Boltzmann equation:

$$
C_{m}=\frac{\alpha Q_{\max } \exp \left[\alpha\left(V_{m}-V_{p k c m}\right)\right]}{\left\{1+\exp \left[\alpha\left(V_{m}-V_{p k c m}\right)\right]\right\}^{2}}+C_{l i n}
$$

where $\alpha$ is the slope factor of the voltage-dependence of charge transfer, $Q_{\max }$ is the maximum charge transfer, $\mathrm{V}_{\mathrm{m}}$ is the membrane potential, $\mathrm{V}_{\mathrm{pkcm}}$ is the voltage at which the maximum charge movement is attained, and $\mathrm{C}_{\text {lin }}$ is the linear capacitance [20].

\section{Immunostaining and anatomical measurements}

Mice were cardiac perfused with $4 \%$ paraformaldehyde and cochleae extracted. After post-fixation and decalcification, cochleae were dissected following the EatonPeabody Laboratory cochlear dissection protocol [28]. In order to detect prestin, $\mathrm{N}$-terminal prestin rabbit antisera [58] was used at 1:1000 with goat anti-rabbit Alexa Fluor 488 (Thermo) as the secondary antibody at 1:500. Alexa 546-conjugated phalloidin and Hoechst 33342 
(Thermo) were also used to stain actin and nuclei, respectively, as described before [45]. Stained cochlear sections were mounted onto slides using Dako fluorescent mounting medium (Agilent). Images were captured on a Nikon A1R confocal microscope with Plan Fluor 10X and Plan Apo 20X objectives (Nikon) controlled by NIS Element software. Basilar membrane length was measured using ImageJ, and the numbers of remaining OHCs determined. A mouse cochlear place-frequency map [32] was used to determine the corresponding frequencies.

\section{Plasmids, cell line and cell culture}

To generate pIZ-499-prestin-ceGFP, pIZ-gPres-ceGFP that contained full-length gerbil prestin with the C-terminal V5 and GFP tag in the pIZ-V5/His vector (Thermo Fisher) [45] was mutagenized using QuickChange Site-Directed Mutagenesis Kit (Agilent) following the manufacturer's instructions. To introduce 499 mutations (V499G/Y501H) [58], the following primers were used: gPres V499A/Y501H A (5' - CATTGCTCTGCTGA CTGGGATCCACAGAACCCAGAGTCC - $3^{\prime}$ ) and gPres V499A/Y501H B (5'- GGACTCTGGGTTCTGTGGA TCCCAGTCAGCAGAGCAATG -3'). Sf9 cells (Thermo Fisher) were maintained in Sf-900 III SFM supplemented with $5 \%$ fetal bovine serum (Gibco) and $1 \mathrm{X}$ antibiotic antimycotic solution (Sigma). To generate stable Sf9 cells expressing 499-prestin protein, Sf9 cells were transfected with pIZ-499-prestin-V5_ceGFP using Effectene (Qiagen), and selected with $1 \mu \mathrm{g} / \mu \mathrm{l}$ zeocin (Thermo Fisher). A single clone was chosen to establish the stable cell line. Generation of the stable sf9-prestin-ceGFP cell line, which expresses WT prestin, was previously reported [45].

\section{Cholesterol binding assay}

Pre-washed CarboxyLink coupling gel was processed with or without cholesteryl hemisuccinate to prepare cholesterol-beads and unconjugated control-beads for non-specific binding as described before [45]. Cell lysates containing membrane fractions isolated from stable Sf9 cells expressing WT-prestin and 499-prestin were mixed with cholesterol-beads or unconjugated control beads and incubated for $1 \mathrm{~h}$ at room temperature. The reaction mix was then centrifuged and washed 5 times with $50 \mathrm{mM}$ Tris- $\mathrm{Cl}$ (pH 7.5) buffer containing $50 \mathrm{mM}$ $\mathrm{NaCl}$ and $20 \mathrm{mM}$ DDM (n-dodecyl $\beta$-D-maltoside), and eluted with 2X Laemmli Sample Buffer (BioRad). Eluates were analyzed by Western blotting as described [45].

\section{Results}

Preservation of prestin expression and motor function in OHCs of NPC1-KO mice

Niemann-Pick Disease Type $\mathrm{C} 1$ is a fatal genetic neurovisceral disorder characterized by a failure to traffic intracellular cholesterol [51]. It is also known that the metabolic status of cholesterol in NPC1-KO mice influences gene and protein expression patterns [10]. Since cholesterol can affect prestin oligomerization, localization to the lateral membrane, and lipid raft association [37, 38], we examined whether prestin is properly expressed and localized in OHCs of NPC1-KO mice. As shown in Fig. 1a-b, OHCs appear normal in cochlear samples from NPC1-KOs $(n=3)$ with prestin expression patterns similar to WT $(n=2)$. Like WT, prestin localizes exclusively at the lateral membrane, suggesting that lack of NPC1 protein does not influence prestin-expression in OHCs (Fig. 1c).

To evaluate prestin's electromotility, we measured and compared nonlinear capacitance (NLC) of OHCs isolated from WT and NPC1-KO mice. Figures 1d-g summarize the NLC measurements, which provide a signature of prestin's motor activity $[2,40]$. There was no statistically significant difference in the charge density (Fig. 1e) between WT and NPC1-KO. This parameter, charge density $\left(\mathrm{CD}\right.$, defined as $\mathrm{Q}_{\max } / \mathrm{C}_{\text {lin }}$ ), normalizes the amount of prestin activity to cell size, such that $\mathrm{Q}_{\max }$ correlates with the amount of functional prestin expressed in the cell membrane, and $\mathrm{C}_{\mathrm{lin}}$ is an indication of $\mathrm{OHC}$ size. These data are consistent with the staining results, indicating that similar amounts of prestin protein were expressed in adult WT and NPC1-KO OHCs. We did, however, observe significant changes in alpha (Fig. 1f), which indicates voltage sensitivity, as well as a depolarizing shift in $\mathrm{V}_{\text {pkcm }}$ (Fig. 1g). These observations are consistent with previous reports showing that cholesterol affects the sensitivity of prestin, and decreasing cholesterol in the membrane shifts $\mathrm{V}_{\text {pkcm }}$ in the depolarizing direction $[21,37,45]$. Hence, the fact that $\mathrm{OHCs}$ from NPC1-KO mice have a more depolarized $\mathrm{V}_{\mathrm{pkcm}}$ suggests that the cholesterol content of the membrane in NPC1-KO mice could be lower than that of $\mathrm{OHCs}$ from WT mice [52]. Taken together, lack of NPC1 does not affect prestin expression and membrane targeting. However, prestin's sensitivity and $\mathrm{V}_{\mathrm{pkcm}}$ are altered, which could relate to a reduction in the cholesterol content of the OHC's plasma membrane in NPC1-KO mice.

\section{Reduced sensitivity and OHC loss in NPC1-KO mice}

Prestin provides the molecular basis for $\mathrm{OHC}$ somatic electromotility $[5,59]$ and is essential for normal hearing $[16,29]$. To investigate whether the function of OHCs in NPC1-KO mice is affected by lack of NPC1 in vivo, we compared DPOAEs in WT and NPC1-KO mice, since this metric is associated with $\mathrm{OHC}$ integrity [3]. As shown in Fig. 2, DPOAE magnitudes in NPC1-KO mice are similar to WT littermates at low frequencies at P21-P54 (Fig. 2a-d). In contrast and similar to previous results [23], reduced sensitivity is observed at high 

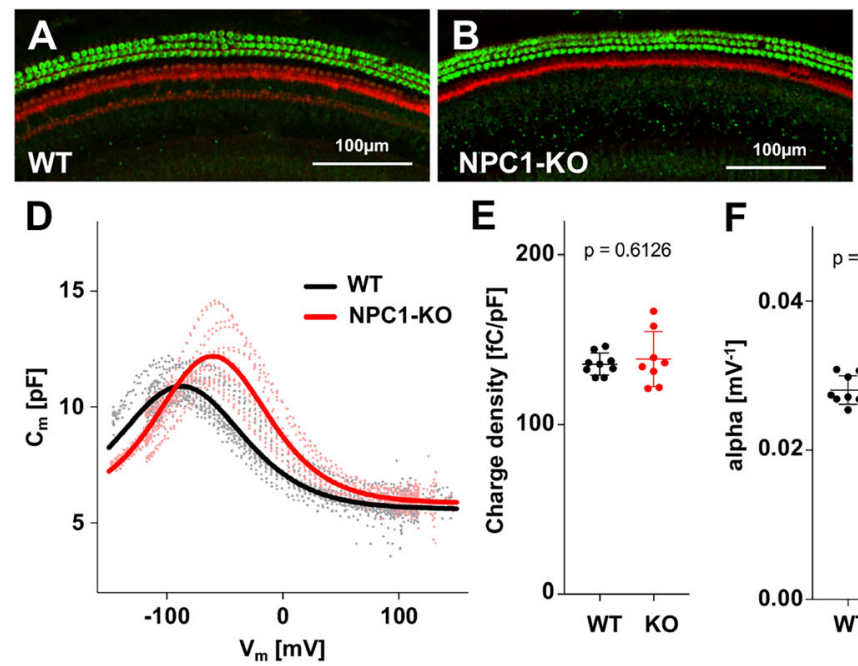

$\mathbf{F}$

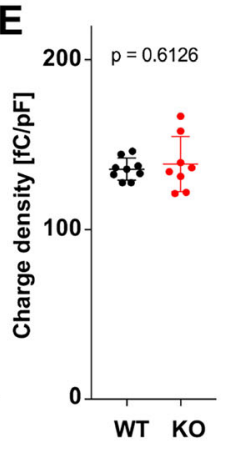

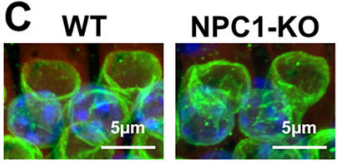

$\mathbf{G}$ $\mid p=0.0142$

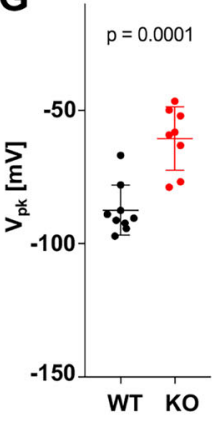

Fig. 1 Prestin expression and function in NPC1-KO mice. $\mathbf{a}-\mathbf{b}$ Immunofluorescent images of OHCs from WT and NPC1-KO mice showing normal prestin expression. Representative images from the middle of the cochlea in a P49 female WT (a) and P49 male NPC1-KO (b), stained with anti-Nmprestin (green) and phalloidin-Alexa 546 (red) showing normal prestin expression. Scale bars, $100 \mu \mathrm{m}$. c. 3D reconstruction of z-stack images of OHCs from P49 male WT and female NPC1-KO cochleae (scale bar, $5 \mu \mathrm{m}$ ), showing the characteristic cylindrical staining of prestin at the lateral membrane. Red, phalloidin (actin); Blue, nuclei. d-g. NLC measurements of OHCs isolated from two female P52 WT and one female P78 and two male P29 NPC1-KO mice. $\mathbf{d}$ Individual recordings of NLC are shown in gray (WT) and pink (NPC1-KO), and the solid black (WT) and red (NPC1-KO) lines indicate fitted curves. e Charge density (CD). Mean \pm s.d. are: WT, $135.5 \pm 6.5 \mathrm{fC} / \mathrm{pF}(n=9)$; NPC1-KO, $138.6 \pm 16.2 \mathrm{fC} / \mathrm{pF}(n=8)$. $\boldsymbol{F}$ alpha. Mean \pm s.d. are: $\mathrm{WT}, 0.028 \pm 0.002 \mathrm{mV}^{-1}(n=9) ; \mathrm{NPC1}-\mathrm{KO}, 0.031 \pm 0.003 \mathrm{mV}^{-1}(n=8) . \mathbf{g} \vee_{\text {pkcm. }}$. Mean \pm s.d. are: WT, $-87.41 \pm 9.3 \mathrm{mV}(n=9) ; \mathrm{NPC1}-$ $\mathrm{KO},-60.57 \pm 12.0 \mathrm{mV}(n=8) . P$ values are indicated in each figure (unpaired t-test)
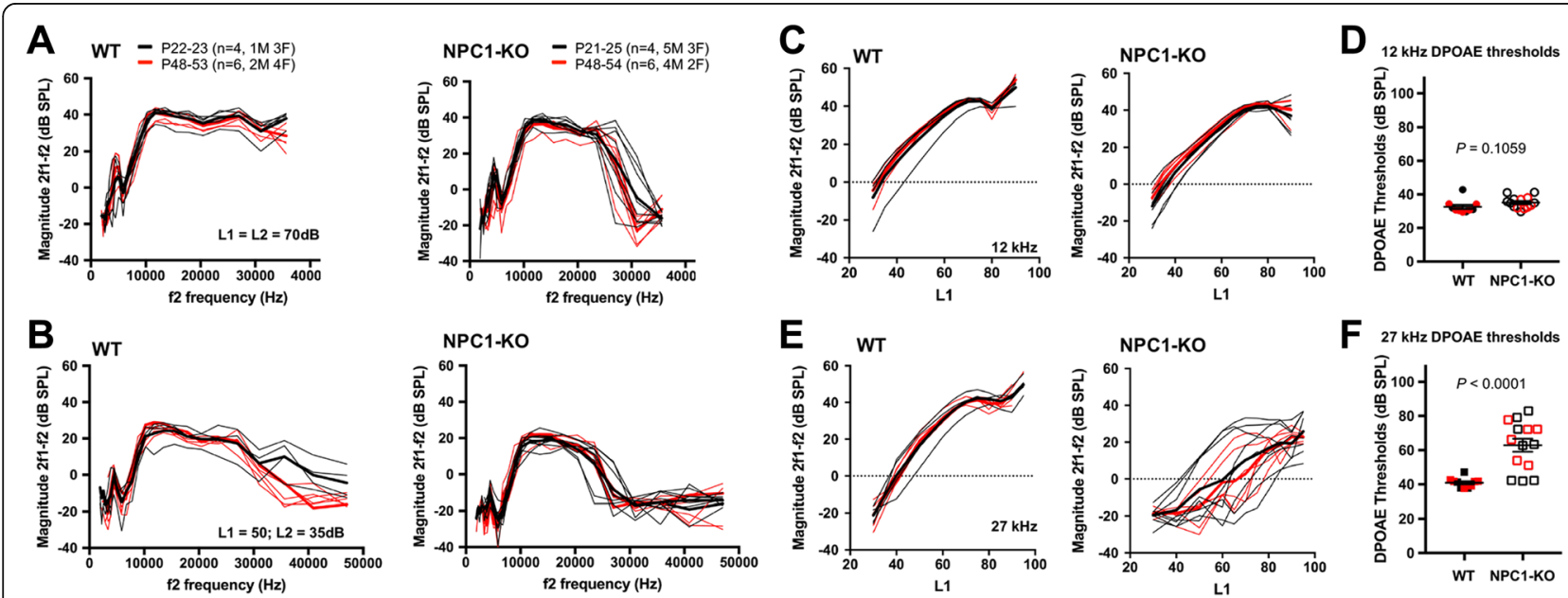

Fig. 2 In vivo physiology of $W T$ and NPC1-KO mice. a-b DP-grams ( $f 2 / f 1=1.2)$ for mean $2 f 1-f 2$ at high $(L 1=L 2=70 \mathrm{~dB}$, a) and moderate $(L 1=$ $50 \mathrm{~dB} ; \mathrm{L} 2=35 \mathrm{~dB}, \mathbf{b}$ ) stimulus levels for WT and NPC1-KO mice at P21-25 (black lines) and P48-54 (red lines). Numbers (n) and sexes of the mice ( $M$, male; F, female) are also indicated. Thin black and red lines are individual traces. In 2B, responses at $\mathrm{f} 2=40,910$ and 35,625 Hz for older (4854) mice were significantly reduced ( $p=0.03$ and 0.0063 , respectively) as compared to younger (P21-25) animals. c-f DPOAE input-output functions collected when the level for $\mathrm{f} 1$ is $10 \mathrm{~dB}$ higher than that for $\mathrm{f} 2 \mathrm{at} \mathrm{f} 2=12 \mathrm{kHz}(\mathbf{c}-\mathbf{d})$, and $\mathrm{f} 2=27 \mathrm{kHz}$ (e-f). DPOAE thresholds for $12 \mathrm{kHz}$ (d) and $27 \mathrm{kHz}(\mathbf{f})$ are also plotted based on the input-output functions in (c) and (e), respectively. Threshold is defined as the level of $\mathrm{f} 1$ that generates a DPOAE at 2f1- $\mathrm{f} 2$ of $0 \mathrm{~dB}$. The black color indicates data points from P21-25 mice while the red color designates P48-54 mice. At $\mathrm{f2}=$ $27 \mathrm{kHz}$, DPOAE thresholds of NPC1-KO mice are significantly elevated compared to WT 
frequencies $(27 \mathrm{kHz})$ in both male and female mice. In fact, the WT results in Fig. 2b show a statistically significant reduction in DPOAE magnitudes at high $\mathrm{f} 2$ frequencies in the older cohort (red, P48-P53), consistent with the known age-related hearing loss in the albino $\mathrm{BALB} / \mathrm{c}$ strain [56]. These changes are exacerbated in mice lacking NPC1 where magnitudes are reduced for $\mathrm{f} 2$ frequencies above $\sim 25 \mathrm{kHz}$. To assay changes in sensitivity, growth functions for the DPOAE at 2f1-f2 are provided in panels $\mathrm{C}$ and $\mathrm{E}$. Again, the results for $\mathrm{f} 2=$ $12 \mathrm{kHz}$ are WT-like in mice lacking NPC1, where DPOAE thresholds (Fig. 2d) are similar to controls. However, the thresholds for $\mathrm{f} 2=27 \mathrm{kHz}$ are raised and highly variable in the NPC1-KO animals (Fig. 2e-f).

To evaluate OHC preservation in NPC1-KO mice, cytocochleograms were constructed for two cochleae from NPC1-KO mice that showed reduced sensitivity at high frequencies. OHC loss was observed in NPC1-KO mice in the basal region, starting around $68 \sim 75 \%$ of the distance from the apex, which is slightly above the $27 \mathrm{kHz}$ place (61.6\%) [32]. OHC loss in WT $(n=2)$ was not observed until $\sim 85 \%$ of the distance from the apex (Fig. 3a). As shown in Fig. 3b-c, more than 50\% of the OHCs were lost in the region located $\sim 75 \%$ of the distance from the apex in NPC1-KO, while OHCs were largely intact in the WT control at the same position. Taken together, apical OHCs in NPC1-KO mice are functionally normal in vivo, while the loss of sensitivity at high-frequencies is at least in part due to the loss of OHCs at the base of cochlea. The fact that WT controls on the BALB/c background also had reduced DPOAEs at high $\mathrm{f} 2$ frequencies, indicates that OHCs just apical to the lesion boundary may not be functional although still present.

\section{OHCs from NPC1-KO mice are still sensitive to $\mathrm{HP} \beta C D$}

$\mathrm{HP} \beta C D$ is more effective in reversing NPC symptoms in the NPC1 $\mathrm{KO}$ mice when delivered directly to the brain because HP $\beta C D$ does not effectively cross the blood-brain barrier (BBB) [6]. For example, a $23 \mathrm{mg} / \mathrm{kg}$ $\mathrm{HP} \beta C D$ intracerebroventricular injection has a better outcome than a $4000 \mathrm{mg} / \mathrm{kg} \mathrm{HP} \beta C D$ subcutaneous injection [1]. Similar to BBB, the blood labyrinthine barrier (BLB) in the cochlea also limits chemical transportation between blood and cochlear fluids. Using a clinical-grade LC/MSMS method of quantifying $\mathrm{HP} \beta C D$, Crumling and colleagues found that the concentration of $\mathrm{HP} \beta C D$ detected in the cochlear fluids $3 \mathrm{~h}$ after $8000 \mathrm{mg} / \mathrm{kg}$ injection was $\sim 128 \mu \mathrm{M}$, far below typical cytotoxic levels of $\mathrm{HP} \beta C D$ [14], and in the range suggested for treating NPC patients: $<1 \mathrm{mM}$ or $100-400 \mu \mathrm{M}[1,31]$. Previously, injections of $4000 \mathrm{mg} / \mathrm{kg} /$ week of $\mathrm{HP} \beta C D$ have been shown to increase the life span of NPC1-KO mice but cause loss of sensitivity $[48,53,55]$. Since $\mathrm{HP} \beta C D$ selectively kills OHCs in WT mice and produces threshold shifts, we examined whether this is also the case for NPC1-KO mice. First, we injected $4000 \mathrm{mg} / \mathrm{kg} /$ week to WT controls and their NPC1-KO littermates, starting after weaning $(\sim \mathrm{P} 21)$ for 4 weeks and measured DPOAEs and ABRs before the first ("Before") and after the last injection ("After"). Because of the variability of the high-frequency responses for NPC1-KO mice on the $\mathrm{BALB} / \mathrm{c}$ background, we evaluated DPOAE thresholds at $\mathrm{f} 2=12 \mathrm{kHz}$ before or after HP $\beta C D$ injections $(4000 \mathrm{mg} /$ $\mathrm{kg} \times 4$ ). As shown in Fig. 4a, DPOAE thresholds at $12 \mathrm{kHz}$ were significantly increased by $\mathrm{HP} \beta C D$ treatment $(4000 \mathrm{mg} / \mathrm{kg} \times 4)$ in all WT mice tested. In addition, the in vivo measurements also showed loss of DPOAEs at all $\mathrm{f} 2$ frequencies (Additional file 1: Figure S1). As expected, this change in phenotype is due to the loss of $\mathrm{OHC}$ function, as anatomical examination of the HPßCD-treated WT mice showed massive OHC loss with only a few OHCs remaining near apex (black and gray lines, Fig. 4b). In contrast, responses in NPC1-KO mice were binary: three out of six animals (two males
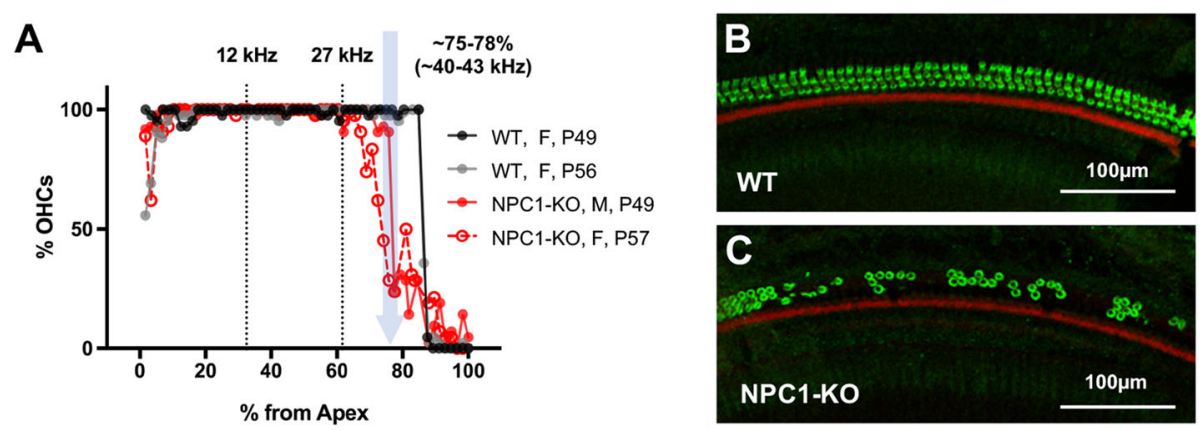

Fig. $3 \mathrm{OHC}$ loss in the basal region of the cochlea in NPC1-KO mice. a. Cytocochleograms of WT and NPC1-KO littermates from a heterozygous breeder pair, where the $\% \mathrm{OHC}$ survival is plotted along the length of cochlea. Vertical black dotted lines indicate the regions corresponding to 12 and $27 \mathrm{kHz}$. b-c Immunofluorescent images showing the basal region ( 75\% of the distance from the apex, as indicated by the pale blue arrow in (a) for a P56 female WT (b) and a P49 male NPC1-KO (c) In this region, scattered OHC loss is observed in NPC1-KO but not in WT. Whole-mount OC sections were stained with anti-N-mprestin antibody (green) and phalloidin-Alexa 546 (red). Scale bars, $100 \mu \mathrm{m}$ 
A DPOAE Thresholds $(12 \mathrm{kHz})$

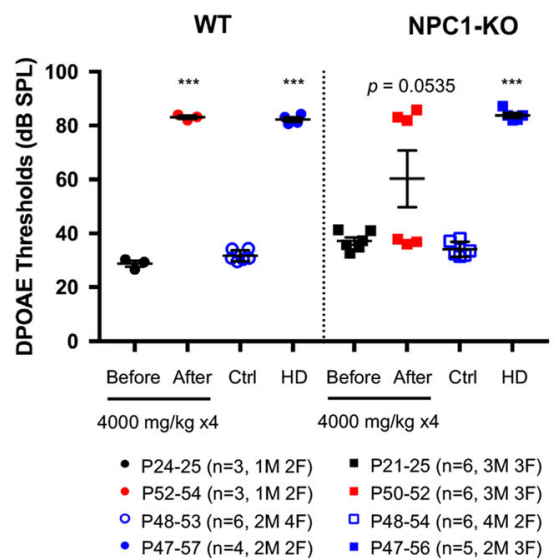

B OHC loss

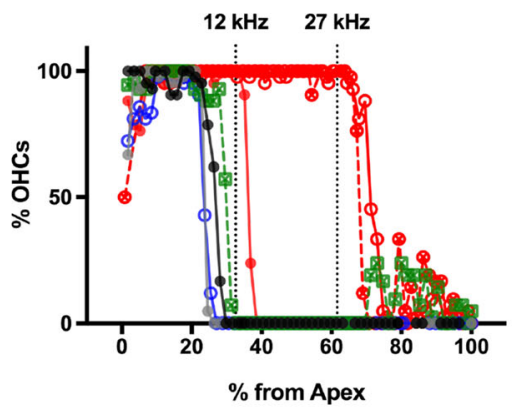

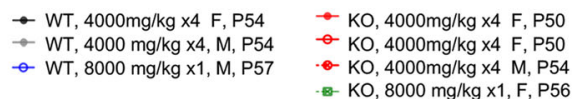

Fig. $4 \mathrm{OHCs}$ of NPC1-KO mice remain susceptible to HPBCD. a DPOAE thresholds at $\mathrm{f} 2=12 \mathrm{kHz}$ of WT and NPC1-KO mice before and after four weekly injections of $4000 \mathrm{mg} / \mathrm{kg} \mathrm{HP} \beta C D$ are plotted. Mice receiving single injections of high-dose (HD) HP $\beta C D$ at $8000 \mathrm{mg} / \mathrm{kg}$ and their agematched controls (Ctrl) are also shown. Each dot represents one mouse. Numbers and sexes are also indicated. Statistical significance is indicated by three asterisks ( $p<0.001$, two-tailed t-test). Variations in sensitivity to low-dose HPßCD in NPC1-KO ("After") is not sex-dependent. $\mathbf{b}$ Cytocochleograms of WT and NPC1-KO mice that received four injections of $4000 \mathrm{mg} / \mathrm{kg} \mathrm{HP \beta CD}$ or single injection of $8000 \mathrm{mg} / \mathrm{kg} \mathrm{HP} \beta C D$ from (a) NPC1-KO mice receiving the low dose HPBCD injections showed large variations in OHC loss that correspond to the DPOAE thresholds. NPC1$\mathrm{KO}$ mice treated with high dose $\mathrm{HP} \beta C \mathrm{C}$ exhibit greater $\mathrm{OHC}$ loss than the low-dose groups

and one female) exhibited threshold shifts as in WT mice, whereas the other three mice ( 1 male and two females) did not show any change in DPOAE thresholds at $12 \mathrm{kHz}$ for the $4000 \mathrm{mg} / \mathrm{kg} \times 4$ injections. Thus, variations in sensitivity to low-dose HP $\beta C D$ in NPC1-KOs ("After") are not sex-dependent. Consistent with this result, HP $\beta C D$-treated NPC1-KO mice with normal thresholds retained most of their OHCs (Fig. 4b, red open circles with solid lines and crossed circles with red broken lines), similar to cytocochleograms of NPC1-KO mice without $\mathrm{HP} \beta C D$ treatment (Fig. 3a, red lines). In contrast, HP $\beta C D$-treated NPC1-KO mice with increased DPOAE thresholds exhibited massive OHC loss (Fig. 4b, closed red circles and solid lines).

Since some NPC1-KO mice were resistant to $\mathrm{HP} \beta C D$-induced OHC loss and reductions in DPOAEs, we increased the $\mathrm{HP} \beta C D$ dosage to a single administration of $8000 \mathrm{mg} / \mathrm{kg}$, which is known to cause $\mathrm{OHC}$ death within hours [45]. As shown in Fig. 4a, a single injection of $8000 \mathrm{mg} / \mathrm{kg} \mathrm{HP} \beta \mathrm{CD}$ (HD for high dose) caused a statistically significant threshold shift in both WT and NPC-KO mice compared to their corresponding untreated groups (Ctrl) (Fig. 4a, $p<0.001$ ). Although this particular NPC1-KO mouse retained slightly more OHCs with $8000 \mathrm{mg} / \mathrm{kg} \mathrm{HP \beta CD} \mathrm{(Fig.} \mathrm{4b,} \mathrm{green)} \mathrm{than} \mathrm{WT}$ littermates (Fig. 4b, blue), this animal still suffered a vast reduction in the overall numbers of surviving OHCs. Taken together, NPC1-KO mice remain susceptible to $\mathrm{HP} \beta C D$-induced $\mathrm{OHC}$ loss but exhibit large variations in their sensitivity to the low dosage of $\mathrm{HP} \beta C D$ when compared to WT.

\section{Co-administration of salicylate with HPßCD did not} mitigate HP $\beta C D$-induced loss of sensitivity

Since prestin is one of the key determinants of HP $\beta C D$ induced $\mathrm{OHC}$ death, we asked whether the motile function of prestin plays a role. Salicylate, commonly known as aspirin, is a small molecule inhibitor of prestin's electromotility. It is well documented that salicylate reversibly inhibits $\mathrm{OHC}$ function and induces temporary hearing loss by directly interacting with prestin $[33,42]$. Thus, salicylate may mitigate $\mathrm{HP} \beta \mathrm{CD}$-induced $\mathrm{OHC}$ death by inhibiting prestin's electromotile function, should it be involved. To test this hypothesis, we co-administered salicylate with HP $\beta C D$ to both WT and NPC1-KO mice and evaluated their auditory function and the degrees of $\mathrm{OHC}$ loss. We employed two modes of salicylate administration, oral $(3 \mathrm{mg} / \mathrm{ml}$ salicylate in drinking water, "Sal (O)" in Fig. 5a) and intraperitoneal injection ( $245 \mathrm{mg} / \mathrm{kg}$, "Sal (IP)" in Fig. 5b), either alone or in combination with high-dose HP $\beta C D(8000 \mathrm{mg} / \mathrm{kg}$, single injection, "HP" in Fig. 5a-b). DPOAEs and ABRs were measured at the time points outlined in Fig. 5a-b (Black dots). Since salicylate is known to be metabolized within $8 \mathrm{~h}$ in mice [44], the Sal (IP) group was also supplied with salicylate-containing water $(3 \mathrm{mg} / \mathrm{ml})$ for the duration of time indicated (Fig. 5b). For both WT and NPC1-KO, Sal (IP) groups exhibited slight but significant increase in ABR (Fig. 5c) and DPOAE (Fig. 5d, Additional file 1: Figure S2) thresholds as compared to the base line controls before the HP $\beta C D$ injection (Base vs. Sal (IP)). This is consistent with the fact that high-dose salicylate treatment can cause reversible 

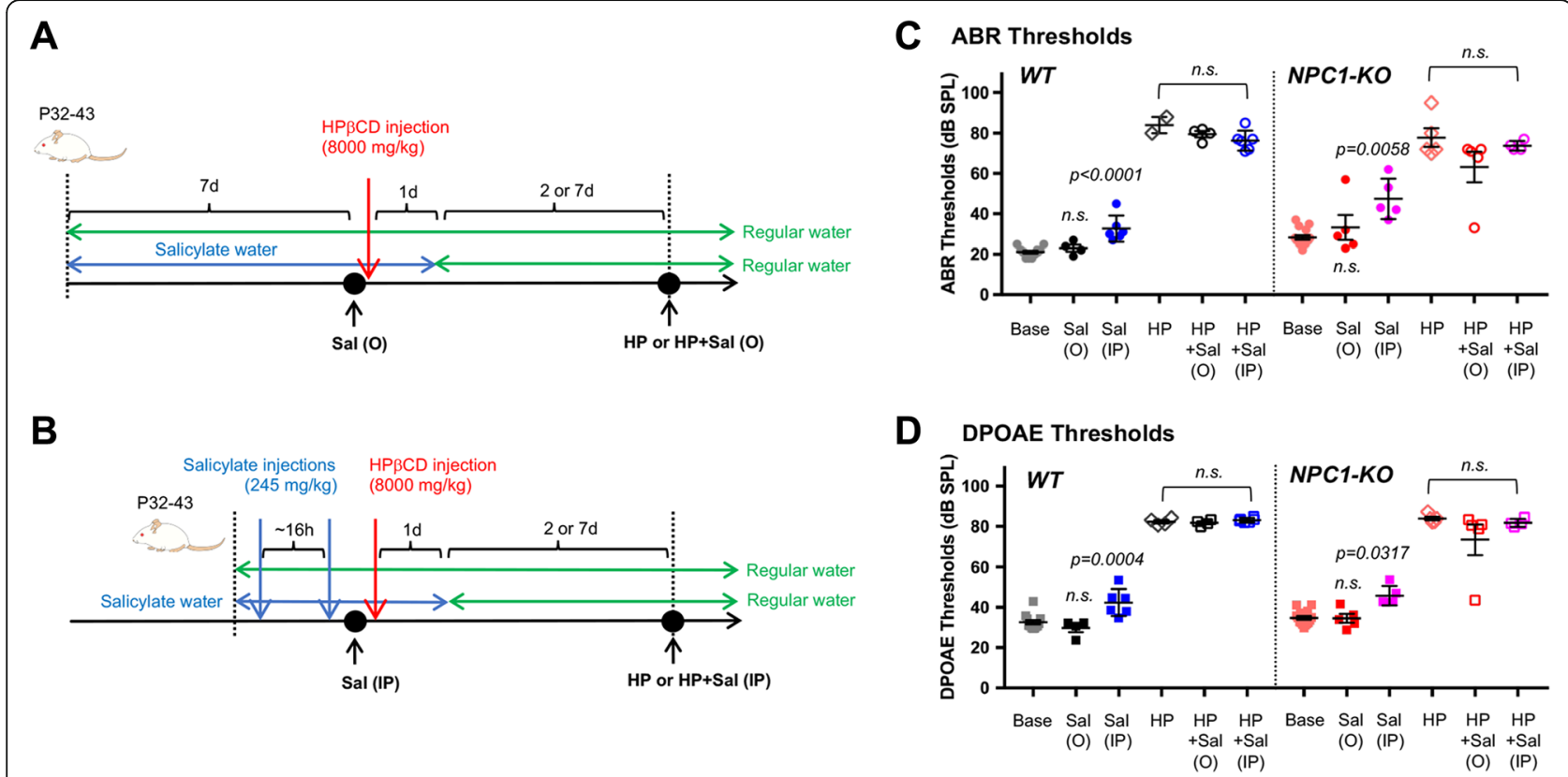

Fig. 5 Salicylate treatment of WT and NPC1-KO mice did not mitigate HPBCD-induced threshold shifts. $\mathbf{a}-\mathbf{b}$ Schematic representation of the protocol for oral administration (a) and intraperitoneal injection (b) of salicylate. c-d ABR (c) and DPOAE (d) thresholds of WT and NPC1-KO mice at $12 \mathrm{kHz}$ before and after high-dose $(8000 \mathrm{mg} / \mathrm{kg}) \mathrm{HP} \beta C D$ injection. Base, baseline controls; HP, regular water, $8000 \mathrm{mg} / \mathrm{kg} \mathrm{HP} \beta C D$ injection; Sal $(\mathrm{O}), 3 \mathrm{mg} / \mathrm{ml}$ salicylate water for 7 days before HP $\beta C D$ injection; HP + Sal $(\mathrm{O}), 3 \mathrm{mg} / \mathrm{ml}$ salicylate water for 7 days before and 1 day after HP $\beta C D$ injection; Sal (IP) 245 mg/kg salicylate injections; HP + Sal (IP), 245 mg/kg salicylate injections before HP $\beta C D$ injection. For WT, Base: $n=12$ (P2253); HP: $n=2$ for ABR (1 male 1 female), $n=4$ for DPOAE ( 2 males, 2 females, P47-57); Sal (O): $n=4$ ( 2 males, 2 females; P50); HP + Sal (O): $n=4$ (2 males, 2 females; P52). For NPC1-KO, Base: $n=16$ (P21-54); HP: $n=4$ (2 males, 2 females; P47-57); Sal (O): $n=5$ ( 2 males 3 females; $P=39-41)$; Sal (IP): $n=5$ (3 males 2 females; $P=31-47) ; H P+$ Sal $(0): n=5$ (2 males 3 females; P41-48); HP + Sal (IP): $n=4$ (2 males 2 females; P33-49). Oneway ANOVA with Tukey's post analysis showed no significant (n.s.) difference between Base vs. Sal (O) or HP vs. HP + Sal (O) or HP + Sal (IP) groups in both WT and NPC1-KO; Sal (IP) groups in WT and NPC1-KO showed statistically significant threshold shifts as compared to Base (P values as indicated)

hearing loss [42]. However, this increase in ABR or DPOAE thresholds was not observed for the mice in Sal $(\mathrm{O})$ groups (Fig. 5c-d, Base vs. Sal $(\mathrm{O})$ ). These results indicate that our protocol for oral administration of salicylate was not sufficient to influence prestin function in the cochlea. Consequently, threshold shifts induced by $\mathrm{HP} \beta C D$ were not mitigated in mice receiving salicylate in the drinking water for both WT and NPC1-KO groups (Fig. $5 \mathrm{c}-\mathrm{d}$, HP vs HP $+\mathrm{Sal}(\mathrm{O})$ ). This was also the case for mice receiving salicylate by IP injections even though salicylate injections before $\mathrm{HP} \beta C D$ injection caused high-frequency ABR threshold shifts and presumably inhibited prestin function (Fig. $5 \mathrm{c}-\mathrm{d}$, HP vs. HP + Sal (IP)). According to $\mathrm{Yu}$ and his colleagues [57], DPOAEs recovered in $\sim 8$ h, i.e., $\mathrm{OHC}$ function was initially inhibited by salicylate. In addition, HP $\beta C D$ reaches the cochlea in $\sim 2 \mathrm{~h}$ and damages $\sim 85 \%$ of OHCs within $8 \mathrm{~h}$ after a single $8000 \mathrm{mg} / \mathrm{kg}$ subcutaneous (SC) injection $[14,45]$. Taken together, these results suggest that HP $\beta C D$-induced ototoxicity is not dependent on prestin's motor function, as inhibition of prestin's electromotility by salicylate did not affect the outcome of HP $\beta C D$-induced ototoxicity in either WT or NPC1-KO.

\section{HP $\beta C D$-induced ototoxicity does not depend on $\mathrm{OHC}$ electromotility}

Although the concentration of $\mathrm{HP} \beta C D$ in various tissues (including the cochlear fluids) and in plasma is highest in the first two hours post-injection [14], the concentration of $\mathrm{HP} \beta C D$ and its elimination rate differ among different tissues. For example, $\mathrm{HP} \beta C D$ in plasma has a half-life $\left(t_{1 / 2}\right)$ of $1.0-1.6 \mathrm{~h}$, while in brain $t_{1 / 2}$ is $6.5 \mathrm{~h} \mathrm{[1}$, 48]. Since the half-life of HP $\beta C D$ in the cochlea is not known, we directly addressed the contribution of prestin's motile function by utilizing a prestin mutant, which carries the V499G/Y501H mutation located near the beginning of prestin's C-terminal domain [58]. 499-prestin can be activated but only at highly depolarized potentials, making it dysfunctional at physiological membrane potentials [20]. Because mutant 499-prestin proteins localize to the lateral membrane $[16,58]$, the OHCs are normal in length and stiffness, which contrasts with the short, compliant $\mathrm{OHCs}$ in mice lacking prestin [29]. Using the 499-prestin KI mouse model, we asked whether non-motile prestin protects against HP $\beta C D$-induced OHC death. To this end, WT and 499 prestin-KI littermates received a one-time injection of either 4000 
or $8000 \mathrm{mg} / \mathrm{kg} \mathrm{HP} \beta C D$ when they were around three-weeks old. Cochlear samples were analyzed a week after injection as previously described [45]. As shown in Fig. 6a-c, 499-prestin-KI mice lose their OHCs just as WT, suggesting that prestin-based somatic electromotility does not contribute to the vulnerability of $\mathrm{OHCs}$ to $\mathrm{HP} \beta C D$. Since WT-prestin directly interacts with cholesterol [45], we also examined whether mutant 499-prestin retains its ability to bind cholesterol. For these experiments, we established stable Sf9 cell lines that express WT or mutant 499-prestin to perform our in vitro cholesterol binding assay $(n=4)$. Equal amounts of cell lysates were incubated with cholesterol-beads and unconjugated beads. As shown in Fig. 6d, 499-prestin proteins expressed in Sf9 cells were pulled down by cholesterol-conjugated beads but not by unconjugated control beads, similar to the WT-prestin. Although prestin's motile function does not appear to underlie the OHC's susceptibility to HP $\beta C D$, the presence of prestin molecules that bind cholesterol may contribute to $\mathrm{HP} \beta C D$-induced $\mathrm{OHC}$ death.

\section{Discussion}

NPC1 disease affects the homeostasis of cellular cholesterol, which can have profound effects on cellular functions. Our evaluation of prestin protein expression and function in OHC of NPC1-KO mice was unaffected, except for the slight yet significant depolarization of the voltage operating point $\left(V_{\text {pkcm }}\right.$, Fig. $\left.1 \mathrm{~g}\right)$. This shift of $\mathrm{V}_{\text {pkcm }}$ in the depolarizing direction indicates a decrease in the amount of cholesterol in the OHC's plasma membrane in NPC1-KO mice, which is plausible considering the altered cellular trafficking of cholesterol [49] and the high frequency threshold shifts in NPC1-KOs evident at weaning (Fig. 2). Although abnormal accumulation of cholesterol was observed in other cell types including spiral ganglion neurons and cells in the stria vascularis of NPC1-KO cochleae [23], OHC loss may be the predominant cause of threshold shifts in the basal high-frequency region in NPC1-KO mice (Fig. 3). High variability observed in this region of the cochlea in NPC1-KO mice may underlie individual variations in the progression of disease, as often noted in NPC1 patients [24].

It is generally understood that $\mathrm{HP} \beta C D$ helps reduce cholesterol accumulation in NPC1 disease by releasing lysosomal cholesterol into the cytoplasm [30, 39, 49]. However, in the cochlea, rapid $\mathrm{OHC}$ loss has been observed in animal models in a dose-dependent manner regardless of the mode of $\mathrm{HP} \beta C D$ administration $[12,13]$. Since prestin is a lateral membrane protein $\mathrm{HP} \beta C D$ likely acts directly on plasma membrane cholesterol to confer its cytotoxic effect on OHCs. Curiously, some of the NPC1-KO mice receiving low-dose $\mathrm{HP} \beta C D(4000 \mathrm{mg} / \mathrm{kg} \times 4)$ were resistant to the cytotoxic effect (Fig. 4a-b). This resilience may simply be a result of individual variations; however, it may also relate to the reduced plasma membrane cholesterol level in OHCs of NPC1-KO mice, revealed by NLC measurement (Fig. 1d, g). We do not fully understand what factors contribute to the variations observed in our data or the data in other publications. For example, multiple injections of $4000 \mathrm{mg} / \mathrm{kg}$ $\mathrm{HP} \beta C D$ did not cause permanent ototoxicity in FVB/ NJ mice [13], while $\mathrm{BALB} / \mathrm{c}$ mice lost a significant number of $\mathrm{OHCs}$ after 4 injections of $4000 \mathrm{mg} / \mathrm{kg}$ $\mathrm{HP} \beta C D$. This information suggests that $\mathrm{OHC}$ sensitivity to $\mathrm{HP} \beta C D$ is influenced by strain background,
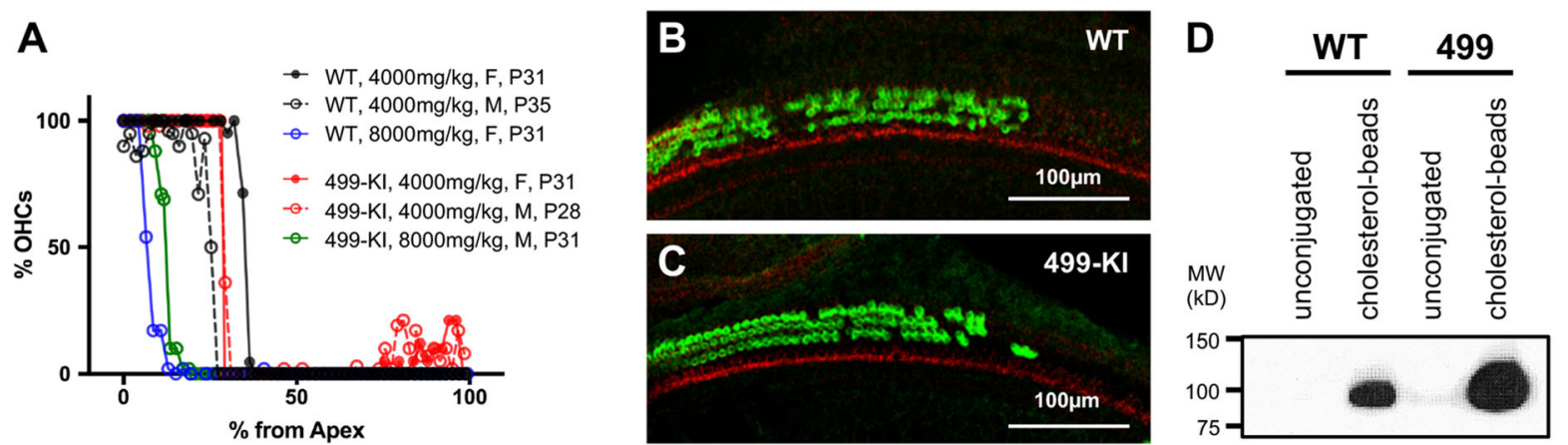

$\alpha-\mathrm{V} 5$

Fig. 6 Non-motile OHCs are still sensitive to HPBCD. a Cytocochleograms of WT and 499-prestin-KI mice after HPßCD treatment (4000 mg/kg or $8000 \mathrm{mg} / \mathrm{kg}$ ). Age and sex of mice are indicated. b-c. Immunofluorescent images of the OC from a P35 male WT (b) and a P28 male $499-$ prestin$\mathrm{KI}$ (c) one week after a single $4000 \mathrm{mg} / \mathrm{kg} \mathrm{HP \beta CD}$ injection. Images were obtained $\sim 27 \%$ of the distance from apex to show the beginning of the $\mathrm{OHC}$ lesion boundary. Cochlear whole mount sections were stained with anti-N-mprestin antibody (green) and phalloidin-Alexa 546 (red). Scale bars, $100 \mu \mathrm{m}$. d Cholesterol pull-down assay $(n=4)$. Cell lysates containing membrane fractions from stable Sf9 cells expressing WT-prestinV5-GFP or 499-prestin-KI-V5-GFP were incubated with unconjugated control beads or cholesterol-conjugated beads, separated on SDS-PAGE, and probed with anti-V5. Both WT-prestin-V5-GFP and 499-prestin-KI-V5-GFP are pulled-down with cholesterol-conjugated beads but not with unconjugated beads 
which may also underlie the variations observed in human patients.

As one of the contributors to HP $\beta C D$-induced ototoxicity, prestin provides a potential molecular target for ameliorating unwanted side effect of $\mathrm{HP} \beta C D$. Because salicylate is a small-molecule inhibitor of prestin's motile function that was shown to have no adverse effect on NPC1-KO mice [43], we tested both oral and systemic administration protocols. Oral administration of salicylate failed to confer an inhibitory effect on prestin function (Fig. 5a). In contrast, direct systemic injection of salicylate increased ABR and DPOAE thresholds, indicative of prestin inhibition (Fig. 5b). However, it did not mitigate the ototoxic effects of $\mathrm{HP} \beta C D$ in either WT or in NPC1-KO mice. Thus, although potentially attractive, inhibition of prestin's function by salicylate did not mitigate $\mathrm{HP} \beta C D$-induced threshold shifts at the doses used in this report.

This conclusion was also corroborated by using 499-prestin-KI mice that express mutated prestin protein with virtually no motile function in vivo. Unlike prestin-KO mice, 499-prestin-KIs were as sensitive to $\mathrm{HP} \beta C D$ as WT (Fig. 6a-c), indicating that somatic electromotility per se is not directly linked to $\mathrm{HP} \beta C D$ susceptibility. The lateral wall of the $\mathrm{OHC}$ is highly specialized and consists of a trilaminate structure that includes an actin/spectrin-based cortical lattice and subsurface cisternae, linked to the prestin-embedded plasma membrane to form a distinct functional domain [26]. As an integral component of this trilaminate structure, prestin plays an important structural role [46]. Since prestin can directly interact with cholesterol [45], it is likely that the prestin-cholesterol interaction contributes to the stability of this specialized membrane domain. As 499-prestin retains its ability to bind cholesterol (Fig. 6d), it is similarly affected by $\mathrm{HP} \beta C D$ treatment as in WT.

Our study provides a detailed characterization of prestin expression and function in $\mathrm{OHCs}$ in the context of NPC1 disease. Although potentially promising, our study indicates that specifically targeting prestin did not provide protection of $\mathrm{OHCs}$ in response to $\mathrm{HP} \beta \mathrm{CD}$. Future efforts for the treatment of NPC1 disease should include effective drug delivery to avoid cochlear exposure, development of alternative small molecules that are more specific or non-toxic [4, 47], and gene therapy [7].

\section{Conclusions}

- OHCs in NPC1-KO mice have normal prestin expression and motor function.

- $\mathrm{HP} \beta C D$-induced ototoxicity is not dependent on prestin's motile function.
- Salicylate, at the doses used in this report, does not mitigate HP $\beta C D$-induced ototoxicity in NPC1-KO mice.

\section{Additional file}

Additional file 1: Figure S1. A. DP-grams for $2 f 1-f 2$ at high $(\mathrm{L} 1=\mathrm{L} 2=$ $70 \mathrm{~dB}$ ) stimulus levels for the same WT and NPC1-KO mice shown in Fig. $4 \mathrm{~A}$. Black lines show before and red lines after four weekly injections of $4000 \mathrm{mg} / \mathrm{kg}$ HPßCD treatments. Blue lines show responses of mice receiving a single administration of $8000 \mathrm{mg} / \mathrm{kg}$ HPBCD. B. DPOAE inputoutput functions of the same mice in $A$ and $B$, showing responses for $f 2$ $=12 \mathrm{kHz}(f 2 / f 1=1.2)$. Figure S2. Salicylate treatment of WT and NPC1-KO mice did not mitigate HPBCD-induced threshold shifts. A-B. DP-grams and input-output functions of Sal $(\mathrm{O})$ and $\mathrm{HP}+\mathrm{Sal}(\mathrm{O})$ groups from Fig. 5A, C-D are shown in A. WTs. B. NPC1-KOs. C-D. DP-grams of Sal (IP) and $\mathrm{HP}+\mathrm{Sal}(\mathrm{IP})$ groups from Fig. 5B, C-D are shown. C. WTs. D. NPC1-KOs. (PDF $1136 \mathrm{~kb}$ )

\section{Acknowledgments}

Imaging was performed at the Northwestern University's Center for Advanced Microscopy generously supported by an NCI CCSG P30 CA06553 award to the Robert H Lurie Comprehensive Cancer Center. This work was supported by the Ara Parseghian Medical Research Fund to J.Z. and a Hugh Knowles Leadership Fund Award to J.Z. by the Knowles Hearing Center.

\section{Authors' contributions}

YZ performed drug admission, ABR and DPOAE measurement, and collected $\mathrm{OHCs}$ for NLC measurement. ST performed immunostaining and anatomical measurements of WT and NPC-KO mice, analyzed data, and prepared figures. $\mathrm{KH}$ performed NLC measurement. CD performed cholesterol binding assay. $J Z$ performed immunostaining and anatomical measurements of 499-KI mice. MAC involved in experimental design. JZ established Sf9 stable cell lines and designed the study. ST, MAC, and JZ wrote the manuscript with input from all other authors. All authors read and approved the final manuscript.

\section{Competing interests}

The authors declare that they have no competing interests.

\section{Publisher's Note}

Springer Nature remains neutral with regard to jurisdictional claims in published maps and institutional affiliations.

\section{Author details}

${ }^{1}$ Department of Communication Sciences and Disorders, Northwestern University, Evanston, IL 60208, USA. ²Department of Otolaryngology - Head and Neck Surgery, Feinberg School of Medicine, Northwestern University, Chicago, IL 60611, USA. ${ }^{3}$ Knowles Hearing Center, Northwestern University, Evanston, IL 60208, USA.

Received: 3 August 2018 Accepted: 13 September 2018

Published online: 24 September 2018

\section{References}

1. Aqul A, Liu B, Ramirez CM, Pieper AA, Estill SJ, Burns DK, Liu B, Repa JJ, Turley SD, Dietschy JM (2011) Unesterified cholesterol accumulation in late endosomes/lysosomes causes neurodegeneration and is prevented by driving cholesterol export from this compartment. J Neurosci 31(25): 9404-9413

2. Ashmore JF (1991) The electrophysiology of hair cells. Annu Rev Physiol 53:465-476

3. Avan P, Bonfils P, Gilain L, Mom T (2003) Physiopathological significance of distortion-product otoacoustic emissions at 2f1-f2 produced by high-versus low-level stimuli. J Acoust Soc Am 113(1):430-441

4. Brown A, Patel S, Ward C, Lorenz A, Ortiz M, DuRoss A, Wieghardt F, Esch A, Otten EG, Heiser LM et al (2016) PEG-lipid micelles enable cholesterol efflux in Niemann-pick type C1 disease-based lysosomal storage disorder. Sci Rep 6:31750 
5. Brownell WE, Bader CR, Bertrand D, de Ribaupierre Y (1985) Evoked mechanical responses of isolated cochlear outer hair cells. Science 227(4683):194-196

6. Calias P (2017) 2-Hydroxypropyl-beta-cyclodextrins and the blood-brain barrier: considerations for Niemann-pick disease type C1. Curr Pharm Des 23(40):6231-6238

7. Chandler RJ, Williams IM, Gibson AL, Davidson CD, Incao AA, Hubbard BT, Porter FD, Pavan WJ, Venditti CP (2017) Systemic AAV9 gene therapy improves the lifespan of mice with Niemann-pick disease, type C1. Hum Mol Genet 26(1):52-64

8. Cheatham MA, Edge RM, Homma K, Leserman EL, Dallos P, Zheng J (2015) Prestin-dependence of outer hair cell survival and partial Rescue of Outer Hair Cell Loss in PrestinV499G/Y501H Knockin mice. PLoS One 10(12): e0145428

9. Cheatham MA, Goodyear RJ, Homma K, Legan PK, Korchagina J, Naskar S, Siegel JH, Dallos P, Zheng J, Richardson GP (2014) Loss of the tectorial membrane protein CEACAM16 enhances spontaneous, stimulus-frequency, and transiently evoked otoacoustic emissions. J Neurosci 34(31):10325-10338

10. Cluzeau CV, Watkins-Chow DE, Fu R, Borate B, Yanjanin N, Dail MK, Davidson CD, Walkley SU, Ory DS, Wassif CA et al (2012) Microarray expression analysis and identification of serum biomarkers for Niemann-pick disease, type C1. Hum Mol Genet 21(16):3632-3646

11. Coisne C, Tilloy S, Monflier E, Wils D, Fenart L, Gosselet F (2016) Cyclodextrins as emerging therapeutic tools in the treatment of cholesterolassociated vascular and neurodegenerative diseases. Molecules 21(12): E1748. https://doi.org/10.3390/molecules21121748.

12. Cronin S, Lin A, Thompson K, Hoenerhoff M, Duncan RK (2015) Hearing loss and Otopathology following systemic and Intracerebroventricular delivery of 2Hydroxypropyl-Beta-Cyclodextrin. J Assoc Res Otolaryngol 16(5):599-611

13. Crumling MA, Liu L, Thomas PV, Benson J, Kanicki A, Kabara L, Halsey K, Dolan D, Duncan RK (2012) Hearing loss and hair cell death in mice given the cholesterol-chelating agent hydroxypropyl-beta-cyclodextrin. PLoS One 7(12):e53280

14. Crumling MA, Ory DS, Jiang X, Duncan RK (2018) Pharmacokinetics of an ototoxic Cyclodextrin in the inner ear measured by LC/MS-MS. In: 41st Meeting of the Assoc Res Otolaryngol San Diego, California

15. Dallos P (1992) The active cochlea. J Neurosci 12(12):4575-4585

16. Dallos P, Wu X, Cheatham MA, Gao J, Zheng J, Anderson CT, Jia S, Wang X, Cheng WH, Sengupta $S$ et al (2008) Prestin-based outer hair cell motility is necessary for mammalian cochlear amplification. Neuron 58(3):333-339

17. Davidson CD, Fishman YI, Puskas I, Szeman J, Sohajda T, McCauliff LA, Sikora J, Storch J, Vanier MT, Szente L et al (2016) Efficacy and ototoxicity of different cyclodextrins in Niemann-pick C disease. Ann Clin Transl Neurol 3(5):366-380

18. Ghosh S, Ghosh C, Nandi S, Bhattacharyya K (2015) Unfolding and refolding of a protein by cholesterol and cyclodextrin: a single molecule study. Phys Chem Chem Phys 17(12):8017-8027

19. Homma K, Dallos P (2011) Evidence that prestin has at least two voltagedependent steps. J Biol Chem 286(3):2297-2307

20. Homma K, Duan C, Zheng J, Cheatham MA, Dallos P (2013) The V499G/ $\mathrm{Y} 501 \mathrm{H}$ mutation impairs fast motor kinetics of prestin and has significance for defining functional independence of individual prestin subunits. J Biol Chem 288(4):2452-2463

21. Kamar Rl, Organ-Darling LE, Raphael RM (2012) Membrane cholesterol strongly influences confined diffusion of prestin. Biophys J 103(8):1627-1636

22. King K, Zalewski C, Farhat N, Keener LA, Hoa M, Bianconi S, Porter FD, Brewer CC (2015) HPßCD therapy in humans with NPC1 disease: audiological outcomes. In: Abstract of 38th Meeting of the Assoc Res Otolaryngol Baltimore, Maryland

23. King KA, Gordon-Salant S, Pawlowski KS, Taylor AM, Griffith AJ, Houser A Kurima K, Wassif CA, Wright CG, Porter FD et al (2014) Hearing loss is an early consequence of Npc1 gene deletion in the mouse model of Niemann-pick disease, type C. J Assoc Res Otolaryngol 15(4):529-54

24. King KA, Gordon-Salant S, Yanjanin N, Zalewski C, Houser A, Porter FD, Brewer CC (2014) Auditory phenotype of Niemann-pick disease, type C1. Ear Hear 35(1):110-117

25. Kumano S, Murakoshi M, lida K, Hamana H, Wada H (2010) Atomic force microscopy imaging of the structure of the motor protein prestin reconstituted into an artificial lipid bilayer. FEBS Lett 584(13):2872-2876

26. Legendre K, Safieddine S, Kussel-Andermann P, Petit C, El-Amraoui A (2008) alphall-betaV spectrin bridges the plasma membrane and cortical lattice in the lateral wall of the auditory outer hair cells. J Cell Sci 121(Pt 20):3347-3356

27. Li J, Pfeffer SR (2016) Lysosomal membrane glycoproteins bind cholesterol and contribute to lysosomal cholesterol export. eLife 5:e21635. https://doi. org/10.7554/eLife.21635.

28. Liberman LD, Suzuki J, Liberman MC (2015) Dynamics of cochlear synaptopathy after acoustic overexposure. J Assoc Res Otolaryngol 16(2): 205-219

29. Liberman MC, Gao J, He DZ, Wu X, Jia S, Zuo J (2002) Prestin is required for electromotility of the outer hair cell and for the cochlear amplifier. Nature 419(6904):300-304

30. Liu B (2012) Therapeutic potential of cyclodextrins in the treatment of Niemann-pick type C disease. Clin Lipidol 7(3):289-301

31. Liu B, Ramirez CM, Miller AM, Repa JJ, Turley SD, Dietschy JM (2010) Cyclodextrin overcomes the transport defect in nearly every organ of NPC1 mice leading to excretion of sequestered cholesterol as bile acid. J Lipid Res 51(5):933-944

32. Muller M, von Hunerbein K, Hoidis S, Smolders JW (2005) A physiological place-frequency map of the cochlea in the CBA/J mouse. Hear Res 202(1-2):63-73

33. Oliver D, He DZ, Klocker N, Ludwig J, Schulte U, Waldegger S, Ruppersberg JP, Dallos P, Fakler B (2001) Intracellular anions as the voltage sensor of prestin, the outer hair cell motor protein. Science 292(5525):2340-2343

34. Ory DS, Ottinger EA, Farhat NY, King KA, Jiang X, Weissfeld L, Berry-Kravis E, Davidson CD, Bianconi S, Keener LA et al (2017) Intrathecal 2-

hydroxypropyl-beta-cyclodextrin decreases neurological disease progression in Niemann-pick disease, type C1: a non-randomised, open-label, phase 1-2 trial. Lancet 390(10104):1758-1768

35. Ottinger EA, Kao ML, Carrillo-Carrasco N, Yanjanin N, Shankar RK, Janssen M, Brewster M, Scott I, Xu X, Cradock J et al (2014) Collaborative development of 2-hydroxypropyl-beta-cyclodextrin for the treatment of Niemann-pick type C1 disease. Curr Top Med Chem 14(3):330-339

36. Pearce M, Richter CP, Cheatham MA (2001) A reconsideration of sound calibration in the mouse. J Neurosci Methods 106(1):57-67

37. Rajagopalan L, Greeson JN, Xia A, Liu H, Sturm A, Raphael RM, Davidson AL, Oghalai JS, Pereira FA, Brownell WE (2007) Tuning of the outer hair cell motor by membrane cholesterol. J Biol Chem 282(50):36659-36670

38. Rajagopalan L, Organ-Darling LE, Liu H, Davidson AL, Raphael RM, Brownell WE, Pereira FA (2010) Glycosylation regulates prestin cellular activity. J Assoc Res Otolaryngol 11(1):39-51

39. Rosenbaum Al, Zhang G, Warren JD, Maxfield FR (2010) Endocytosis of betacyclodextrins is responsible for cholesterol reduction in Niemann-pick type C mutant cells. Proc Natl Acad Sci U S A 107(12):5477-5482

40. Santos-Sacchi J (1991) Reversible inhibition of voltage-dependent outer hair cell motility and capacitance. J Neurosci 11(10):3096-3110

41. Santos-Sacchi J, Kakehata S, Takahashi S (1998) Effects of membrane potential on the voltage dependence of motility-related charge in outer hair cells of the Guinea-pig. J Physiol Lond 510(Pt 1):225-235

42. Sheppard A, Hayes SH, Chen GD, Ralli M, Salvi R (2014) Review of salicylateinduced hearing loss, neurotoxicity, tinnitus and neuropathophysiology. Acta Otorhinolaryngol Ital 34(2):79-93

43. Smith D, Wallom KL, Williams IM, Jeyakumar M, Platt FM (2009) Beneficial effects of anti-inflammatory therapy in a mouse model of Niemann-pick disease type C1. Neurobiol Dis 36(2):242-251

44. Sturman JA, Dawkins PD, McArthur N, Smith MJ (1968) The distribution of salicylate in mouse tissues after intraperitoneal injection. J Pharm Pharmacol 20(1):58-63

45. Takahashi S, Homma K, Zhou Y, Nishimura S, Duan C, Chen J, Ahmad A, Cheatham MA, Zheng J (2016) Susceptibility of outer hair cells to cholesterol chelator 2-hydroxypropyl-beta-cyclodextrine is prestindependent. Sci Rep 6:21973

46. Takahashi S, Sun W, Zhou Y, Homma K, Kachar B, Cheatham MA, Zheng $J$ (2018) Prestin contributes to membrane compartmentalization and is required for Normal innervation of outer hair cells. Front Cell Neurosci 12:211

47. Tamura A, Yui N (2014) Lysosomal-specific cholesterol reduction by biocleavable polyrotaxanes for ameliorating Niemann-pick type $\mathrm{C}$ disease. Sci Rep 4:4356

48. Tanaka Y, Yamada Y, Ishitsuka Y, Matsuo M, Shiraishi K, Wada K, Uchio Y, Kondo Y, Takeo T, Nakagata N et al (2015) Efficacy of 2Hydroxypropyl-beta-cyclodextrin in Niemann-pick disease type $\mathrm{C}$ model 
mice and its pharmacokinetic analysis in a patient with the disease. Biol Pharm Bull 38(6):844-851

49. Taylor AM, Liu B, Mari Y, Liu B, Repa JJ (2012) Cyclodextrin mediates rapid changes in lipid balance in Npc1-/- mice without carrying cholesterol through the bloodstream. J Lipid Res 53(11):2331-2342

50. Tiwari G, Tiwari R, Rai AK (2010) Cyclodextrins in delivery systems: applications. J Pharm Bioallied Sci 2(2):72-79

51. Vance JE (2006) Lipid imbalance in the neurological disorder, Niemannpick C disease. FEBS Lett 580(23):5518-5524

52. Vance JE, Karten B (2014) Niemann-pick C disease and mobilization of lysosomal cholesterol by cyclodextrin. J Lipid Res 55(8):1609-1621

53. Vite CH, Bagel JH, Swain GP, Prociuk M, Sikora TU, Stein VM, O'Donnell P, Ruane T, Ward S, Crooks A et al (2015) Intracisternal cyclodextrin prevents cerebellar dysfunction and Purkinje cell death in feline Niemann-Pick type C1 disease. Sci Transl Med 7(276):276ra226

54. Wang X, Yang S, Jia S, He DZ (2010) Prestin forms oligomer with four mechanically independent subunits. Brain Res 1333:28-35

55. Ward S, O'Donnell P, Fernandez S, Vite CH (2010) 2-hydroxypropyl-betacyclodextrin raises hearing threshold in normal cats and in cats with Niemann-pick type $C$ disease. Pediatr Res 68(1):52-56

56. Willott JF, Turner JG, Carlson S, Ding D, Seegers Bross L, Falls WA (1998) The $B A L B / c$ mouse as an animal model for progressive sensorineural hearing loss. Hear Res 115(1-2):162-174

57. Yu N, Zhu ML, Johnson B, Liu YP, Jones RO, Zhao HB (2008) Prestin upregulation in chronic salicylate (aspirin) administration: an implication of functional dependence of prestin expression. Cell Mol Life Sci 65(15): 2407-2418

58. Zheng J, Du GG, Matsuda K, Orem A, Aguinaga S, Deak L, Navarrete E, Madison LD, Dallos P (2005) The C-terminus of prestin influences nonlinear capacitance and plasma membrane targeting. J Cell Sci 118(Pt 13):2987-2996

59. Zheng J, Shen WX, He DZZ, Kevin BL, Madison LD, Dallos P (2000) Prestin is the motor protein of cochlear outer hair cells. Nature 405(6783):149-155

Ready to submit your research? Choose BMC and benefit from:

- fast, convenient online submission

- thorough peer review by experienced researchers in your field

- rapid publication on acceptance

- support for research data, including large and complex data types

- gold Open Access which fosters wider collaboration and increased citations

- maximum visibility for your research: over $100 \mathrm{M}$ website views per year

At BMC, research is always in progress.

Learn more biomedcentral.com/submissions 